OPEN ACCESS

Edited by:

Jakub Zieg,

University Hospital in Motol, Czechia

Reviewed by:

Erum Aftab Hartung,

Children's Hospital of Philadelphia,

United States

Se Jin Park,

Yonsei University, South Korea

*Correspondence:

Shuichi Ito

itoshu@yokohama-cu.ac.jp

Specialty section:

This article was submitted to

Pediatric Nephrology,

a section of the journal

Frontiers in Pediatrics

Received: 06 December 2019

Accepted: 02 March 2020

Published: 19 March 2020

Citation:

Togashi H, Shimosato Y, Saida K,

Miyake N, Nakamura T and Ito S (2020) Childhood Nephrotic

Syndrome Complicated by

Catastrophic Multiple Arterial

Thrombosis Requiring Bilateral

Above-Knee Amputation.

Front. Pediatr. 8:107.

doi: 10.3389/fped.2020.00107

\section{Childhood Nephrotic Syndrome Complicated by Catastrophic Multiple Arterial Thrombosis Requiring Bilateral Above-Knee Amputation}

\author{
Hayato Togashi ${ }^{1,2}$, Yuko Shimosato ${ }^{2}$, Ken Saida $^{3}$, Noriko Miyake ${ }^{3}$, Takeshi Nakamura ${ }^{4}$ and \\ Shuichi Ito ${ }^{2 *}$ \\ ${ }^{1}$ Department of Pediatrics, Saiseikai Yokohamashi Nanbu Hospital, Yokohama, Japan, ${ }^{2}$ Department of Pediatrics, Yokohama \\ City University Graduate School of Medicine, Yokohama, Japan, ${ }^{3}$ Department of Human Genetics, Yokohama City University \\ Graduate School of Medicine, Yokohama, Japan, ${ }^{4}$ Department of Rehabilitation Medicine, Yokohama City University \\ Graduate School of Medicine, Yokohama, Japan
}

Background: Thromboembolic events are rare but critical complications in childhood nephrotic syndrome. The veins are more commonly affected, while arterial thrombosis is extremely rare but often life-threatening. Herein, we describe the clinical course of a 10-years-old girl with catastrophic multiple arterial thrombosis at the primary onset of nephrotic syndrome who underwent bilateral above-knee amputation.

Case diagnosis/treatment: A previous healthy 10-years-old girl contracted the influenza B virus. Five days later, she suddenly developed severe ischemia in both legs. Physical examination showed eyelid and leg edema, and laboratory tests revealed hypoalbuminemia and acute kidney injury. After undergoing contrast-enhanced computed tomography, the patient was diagnosed with multiple arterial thrombosis (including the bilateral iliac arteries) due to nephrotic syndrome. Despite the performance of surgical thrombectomies, fasciotomy, and systematic heparinization, she required bilateral above-knee amputation. The patient achieved spontaneous remission of nephrotic syndrome, and her renal function fully recovered. There were no findings suggestive of secondary nephrotic syndrome and antiphospholipid syndrome. Her protein $\mathrm{C}$ and protein $\mathrm{S}$ concentrations were slightly decreased at admission. However, whole-exome sequencing revealed a thrombotic risk variant (T630I) in the PROS1 gene encoding protein $\mathrm{S}$. This missense variant is often reported in patients with thrombosis or protein $\mathrm{S}$ deficiency, and may result in a thrombotic predisposition in some situations, such as nephrotic syndrome.

Conclusions: Arterial thrombosis is a rare complication; however, it must be considered, especially in patients with new-onset nephrotic syndrome. Early recognition is important for early intervention and prevention of serious sequelae.

Keywords: nephrotic syndrome, arterial thrombosis, PROS1 gene, protein S, amputation 


\section{INTRODUCTION}

Thromboembolism is a well-known complication of nephrotic syndrome (NS). The suggested risk factors for thromboembolic complications in children with NS include urinary loss of anticoagulants, increased synthesis of clotting factors, alterations of the fibrinolytic system, thrombocytosis, enhanced platelet activation and aggregation, and blood hyperviscosity due to hemoconcentration (1-3). The incidence of thromboembolic complications in children with NS is reportedly $1.8-4.4 \%$ (4). Veins are most commonly affected $(1,4)$. In contrast, arterial thrombosis is extremely rare, but often becomes serious (4). Herein, we describe a case of primary-onset childhood NS complicated by catastrophic multiple arterial thrombosis that required bilateral above-knee amputation.

\section{CASE PRESENTATION}

A previously healthy 10-years-old girl was transferred to our intensive care unit because of severe ischemia in both legs. She had contracted the influenza B virus 1 week before admission. After 5 days of abdominal pain and vomiting, she had suddenly developed severe pain and cyanosis in both legs on the morning of the day of admission. She was diagnosed with multiple thrombosis based on computed tomography findings at the previous hospital. Physical examination at the time of admission showed eyelid and leg edema and severe cyanosis of both legs. Both legs below the inguinal region had become dark purplecolored and were cold to touch. The bilateral popliteal and dorsalis pedis pulses were markedly diminished. The patient was unable to move due to severe leg pain. The onset of severe pain and cyanosis in both legs had occurred more than $10 \mathrm{~h}$ prior to admission.

On admission, she had a blood pressure of 133/88 mmHg, pulse of 100 beats per minute, and respiratory rate of 22 breaths per minute. Laboratory test results were: urine protein-tocreatinine ratio, $10.7 \mathrm{~g} / \mathrm{gCr}$ (reference: $<0.15 \mathrm{~g} / \mathrm{gCr}$ ); serum albumin, $1.0 \mathrm{~g} / \mathrm{dL}$ (reference: $4.1-5.1 \mathrm{~g} / \mathrm{dL}$ ); total cholesterol, $465 \mathrm{mg} / \mathrm{dL}$ (reference: $142-248 \mathrm{mg} / \mathrm{dL}$ ); urea nitrogen, $68 \mathrm{mg} / \mathrm{dL}$ (reference: $8-20 \mathrm{mg} / \mathrm{dL}$ ); serum creatinine, $0.89 \mathrm{mg} / \mathrm{dL}$ (reference: $0.30-0.57 \mathrm{mg} / \mathrm{dL}$ ); uric acid, $12.1 \mathrm{mg} / \mathrm{dL}$ (reference: $2.6-5.5$ $\mathrm{mg} / \mathrm{dL}$ ); creatinine kinase, 3,858IU/L (reference: 41-153IU/L); sodium, $117 \mathrm{mEq} / \mathrm{L}$ (reference: 138-145mEq/L); potassium, $6.4 \mathrm{mEq} / \mathrm{L}$ (reference: $3.6-4.8 \mathrm{mEq} / \mathrm{L}$ ); fibrinogen degradation products, $447 \mu \mathrm{g} / \mathrm{mL}$ (reference: $<5 \mu \mathrm{g} / \mathrm{mL}$ ); D-dimers, $11.48 \mu \mathrm{g} / \mathrm{mL}$ (reference: $<0.70 \mu \mathrm{g} / \mathrm{mL}$ ); antithrombin III, $66 \%$ (reference: 78-125\%). Laboratory abnormalities suggested NS, acute kidney injury, and rhabdomyolysis.

Contrast-enhanced computed tomography revealed multiple thrombi in the bilateral common iliac, external iliac, and femoral arteries, right pulmonary artery, and right renal artery (Figure 1).

Since cyanosis had developed more than $10 \mathrm{~h}$ before presentation, there was concern that thrombolytic therapy would not be effective due to the likelihood of formation of organized thrombi. Therefore, urgent surgical thrombectomy was performed from the external iliac arteries. Partial removal of thrombi was achieved, but the distal thrombi could not be removed. Most of the thrombi were organized and there were few fresh thrombi, which suggested that the best time to perform thrombolytic therapy had already passed. The patient subsequently developed compartment syndrome in both legs, which required urgent fasciotomy on the day of admission. During surgical thrombectomy, hemodiafiltration was started in the operation room because of anuria due to acute kidney injury and progressive rhabdomyolysis.

Systematic heparinization was initiated. Prednisolone was not started because of the increased risks of thrombosis, infection, and the difficulty in evaluating proteinuria in an anuric patient. Although the popliteal pulses slightly recovered in both legs after surgical thrombectomy, the patient required a second thrombectomy using a Fogarty catheter on the 4th hospital day due to weakened bilateral popliteal and dorsalis pedis pulses. Bilateral above-knee amputations were performed on the 6th hospital day because of the progression of necrosis and suspected infection. Urination had begun and hemodialysis was withdrawn on the $23 \mathrm{rd}$ hospital day. The urine proteinto-creatinine ratio spontaneously decreased, and the patient achieved complete remission of NS on the 44th hospital day. Her renal function also fully recovered. Despite the heparinization, ultrasonography showed a thrombus in the abdominal aorta, which necessitated the addition of clopidogrel on the 26th hospital day. However, an iatrogenic pseudoaneurysm in the right brachial artery was found, and so antithrombotic and antiplatelet agents were discontinued on the 31st hospital day. Contrast-enhanced computed tomography revealed a thrombus in the right internal jugular vein on the 66th hospital day, which required warfarin therapy. The patient was discharged on day 81 . All thrombi had disappeared, and warfarin was withdrawn at 2 months after discharge. The patient is currently able to walk using bilateral artificial legs, and has shown no signs of recurrence of NS and/or thrombosis.

Further evaluation was undertaken to determine the underlying etiology of the arterial thrombosis. Laboratory testing performed while the patient was in the state of NS showed a low antithrombin III level of 66\% (reference: 78-125\%), low protein C activity of $67 \%$ (reference: $70-150 \%$ ), and low protein S level of 56.0\% (reference: 63.5-149.0\%). Factor VII level was normal. Complement study revealed that the $\mathrm{C} 3, \mathrm{C} 4$, and $\mathrm{CH} 50$ levels were within normal limits. Tests for antinuclear antibody, anti-double stranded DNA antibody, lupus anticoagulant, anticardiolipin antibody, and anti-neutrophilic cytoplasmic antibody were all negative. Whole-exome sequencing revealed negativity for factor V Leiden and prothrombin G20210A, which are well-known causes of thrombosis, but showed a missense variant in the PROS1 gene encoding protein S (NM_000313.3: c.1889C>T: Thr630Ile), which is recurrently reported in patients with thrombosis. Thus, we are considering restarting anticoagulant therapy.

\section{DISCUSSION}

The frequency of thromboembolic complications in children with NS is reported to be between 1.8 and $4.4 \%$ (4). 

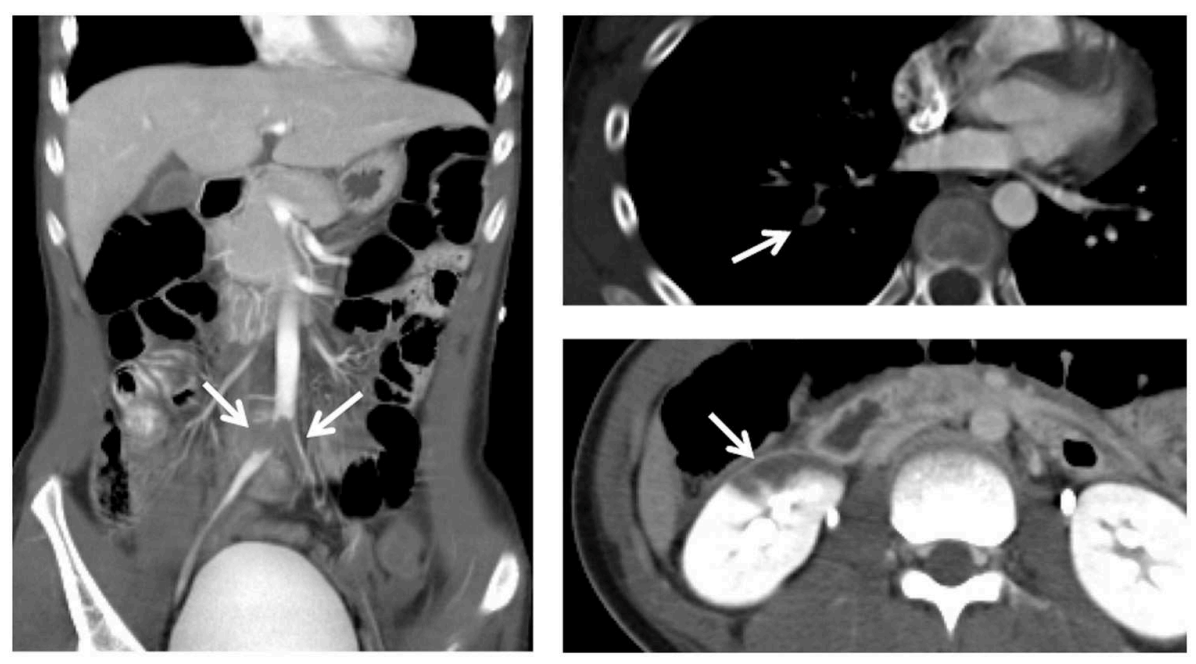

FIGURE 1 | Contrast-enhanced computed tomography reveals multiple thrombi (arrows) in the bilateral common iliac, external iliac, and femoral arteries, right pulmonary artery, and right renal artery.

The hypercoagulable state is multifactorial, attributed predominantly to urinary loss of anticoagulants, increased procoagulatory activity, impaired fibrinolysis, thrombocytosis, platelet hyperaggregability, and blood hyperviscosity due to hemoconcentration (1-3). Thrombotic complications are predominantly venous, but arterial thrombosis can also occur and often becomes serious. A previous single-center study reported 35 thromboembolic events in 34 children with NS over a period of 7 years, including cerebral venous thrombosis ( $n$ $=11$ ), pulmonary thromboembolism $(n=9)$, deep vein and superior vena cava thrombosis $(n=6)$, intracranial arterial thrombosis $(n=7)$, and peripheral arterial thrombosis $(n=2)$ (4). The common sites of arterial thrombosis are the cerebral, pulmonary, and femoral arteries, where turbulent flow occurs from arterial branching $(4,5)$. Arterial thrombosis has also been reported at other sites, such as the abdominal aorta and the renal, mesenteric, and brachial arteries (6).

According to previous reports, thromboembolic events often develop within months of diagnosis and during treatment of NS (7). The risk factors for thromboembolic complications in children with NS are: an age of over 12 years, thromboembolic history preceding the diagnosis of NS, secondary NS, and membranous nephropathy (7). The risk of thromboembolic complications is also increased by dehydration, infection, immobilization, arterial or venous puncture, history of diuretic, or corticosteroid use, presence of hemoconcentration (hemoglobin $>14 \mathrm{~g} / \mathrm{dL}$ ), thrombocytosis $\left(>450 \times 10^{9}\right.$ platelets $\left./ \mathrm{L}\right)$, severe proteinuria, hypoalbuminemia $(<2.0 \mathrm{~g} / \mathrm{dL})$, hyperfibrinogenemia, and hypoantithrombinemia $(<75 \%)(1,3,4,8-10)$. In our case, the bedrest and decreased water intake during influenza $B$ virus infection could have accelerated the thrombogenesis; other risk factors for thrombosis included hypoalbuminemia, hyperfibrinogenemia, and decreased levels of antithrombin III, protein C, and protein S.
Table 1 summarizes 11 cases of arterial thrombosis in the extremities in pediatric idiopathic NS, including the present case (8-17). The median age at the time of the thrombotic event was 8 years (range 1-15 years). Arterial thrombosis occurred during the first episode of NS in five of eight cases $(62.5 \%)$, and corticosteroids were used in seven of 11 cases (63.6\%). Hypoalbuminemia $(<2.0 \mathrm{~g} / \mathrm{dL})$ was observed in five of eight cases, including our case. Surgical thrombectomies were performed in nine of 10 cases $(90.0 \%)$, and amputations were performed in six of 11 cases (55.6\%).

The therapeutic approach to arterial thrombosis in children includes surgical intervention, systematic anticoagulation, and thrombolytic therapy. Tissue plasminogen activator is reportedly effective in pediatric patients; however, its risk-benefit ratio remains unclear (4). Our patient could not undergo thrombolysis therapy because it had been more than $10 \mathrm{~h}$ since the onset of leg pain and cyanosis. Therefore, surgical thrombectomy was performed. As the removed thrombi were almost all organized, thrombolysis therapy was unlikely to have been effective. In our patient, it is likely that organized chronic thrombi had disseminated from the bifurcation site of the common iliac artery and had occluded the femoral artery. Despite multiple interventions including surgical thrombectomies, fasciotomy, and systematic heparinization, our patient regretfully required bilateral above-knee amputation to save her life.

Our patient achieved spontaneous remission of NS and showed no recurrence of NS. The cause of NS in the present case remains unclear without a kidney biopsy, but was presumably due to minimal change NS. Spontaneous remission of minimal change NS has been reported in cases complicated by viral infections such as measles, varicella, and influenza B (18-20). Additionally, trauma induces inflammation, but counter-immunosuppression subsequently develops. There is an increased risk of counter-immunosuppression in injured patients. Such immunosuppression after trauma can induce 
TABLE 1 | Published cases of arterial thrombosis of the extremities in pediatric idiopathic nephrotic syndrome.

\begin{tabular}{|c|c|c|c|c|c|c|c|c|c|c|c|}
\hline References & $\begin{array}{l}\text { Cameron } \\
\text { et al. (11) }\end{array}$ & $\begin{array}{l}\text { Harrison and } \\
\text { Wood (12) }\end{array}$ & $\begin{array}{l}\text { Parrish et al. } \\
\text { (8) }\end{array}$ & $\begin{array}{l}\text { Maffei et al. } \\
\text { (13) }\end{array}$ & $\begin{array}{l}\text { Tarry et al. } \\
\text { (9) }\end{array}$ & $\begin{array}{l}\text { Farkas et al. } \\
\text { (10) }\end{array}$ & $\begin{array}{l}\text { Büyükçelik } \\
\text { et al. (14) }\end{array}$ & $\begin{array}{l}\text { Koh et al. } \\
\text { (15) }\end{array}$ & $\begin{array}{l}\text { Han et al. } \\
\text { (16) }\end{array}$ & $\begin{array}{l}\text { Chinnadurai } \\
\text { et al. (17) }\end{array}$ & Our case \\
\hline Age/sex & $1 / F$ & $3 / \mathrm{M}$ & $8 / \mathrm{M}$ & $1 / \mathrm{M}$ & 15/M & $15 / \mathrm{M}$ & $14 / F$ & $15 / \mathrm{N} / \mathrm{A}$ & $2 / F$ & $8 / \mathrm{M}$ & 10/F \\
\hline $\begin{array}{l}\text { Thromboembolic } \\
\text { site }\end{array}$ & $\begin{array}{l}\text { Popliteal } \\
\text { artery }\end{array}$ & Femoral artery & $\begin{array}{l}\text { Common } \\
\text { iliac, external } \\
\text { iliac, and } \\
\text { femoral } \\
\text { arteries }\end{array}$ & Femoral artery & $\begin{array}{l}\text { Brachial, } \\
\text { ulnar, and } \\
\text { radial arteries }\end{array}$ & $\begin{array}{l}\text { Popliteal } \\
\text { artery }\end{array}$ & $\begin{array}{l}\text { Femoral and } \\
\text { posterior tibial } \\
\text { arteries }\end{array}$ & $\begin{array}{l}\text { Femoral and } \\
\text { popliteal } \\
\text { arteries }\end{array}$ & $\begin{array}{l}\text { Common } \\
\text { iliac, external } \\
\text { iliac, and } \\
\text { popliteral } \\
\text { arteries }\end{array}$ & $\begin{array}{l}\text { Posterior tibial } \\
\text { and peroneal } \\
\text { arteries }\end{array}$ & $\begin{array}{l}\text { Common } \\
\text { iliac and } \\
\text { femoral } \\
\text { arteries }\end{array}$ \\
\hline Episode & $\mathrm{N} / \mathrm{A}$ & $\mathrm{N} / \mathrm{A}$ & Relapse & First & First & Relapse & First & Relapse & First & First & First \\
\hline $\begin{array}{l}\text { Steroid } \\
\text { administration }\end{array}$ & Yes & Yes & Yes & No & No & Yes & No & Yes & Yes & Yes & No \\
\hline Steroid sensitivity & $\mathrm{N} / \mathrm{A}$ & Resistant & Sensitive & Sensitive & N/A & Resistant & Resistant & Sensitive & Resistant & Sensitive & - \\
\hline $\begin{array}{l}\text { Type of nephrotic } \\
\text { syndrome }\end{array}$ & N/A & MPGN & MC & $\mathrm{MC}$ & N/A & $\mathrm{MC}$ & MN & MC & FSGS & FSGS & - \\
\hline Albumin (g/dL) & $\mathrm{N} / \mathrm{A}$ & $\mathrm{N} / \mathrm{A}$ & 0.8 & N/A & 0.4 & 1.8 & 2.2 & 3.8 & 2.5 & 1.4 & 1.0 \\
\hline Fibrinogen ( $\mu \mathrm{g} / \mathrm{dL})$ & $\mathrm{N} / \mathrm{A}$ & $\mathrm{N} / \mathrm{A}$ & N/A & N/A & N/A & 630 & 381 & N/A & 362 & $\mathrm{~N} / \mathrm{A}$ & 949 \\
\hline Antithrombin III (\%) & N/A & N/A & N/A & N/A & N/A & 65 & 83 & $\mathrm{~N} / \mathrm{A}$ & 91 & 46 & 66 \\
\hline Thrombectomy & Yes & $\mathrm{N} / \mathrm{A}$ & Yes & Yes & Yes & Yes & No & Yes & Yes & Yes & Yes \\
\hline Thrombolysis & Yes & $\mathrm{N} / \mathrm{A}$ & No & No & Yes & No & No & No & No & Yes & No \\
\hline Fasciotomy & No & N/A & No & No & Yes & No & No & Yes & No & Yes & Yes \\
\hline Amputation & Femur & $\mathrm{N} / \mathrm{A}$ & Femur & No & $\begin{array}{l}\text { Digits of the } \\
\text { hand }\end{array}$ & Lower leg & No & No & No & $\begin{array}{l}\text { Digits of the } \\
\text { foot }\end{array}$ & $\begin{array}{l}\text { Bilateral } \\
\text { femurs }\end{array}$ \\
\hline
\end{tabular}

N/A, not available; MPGN, membranoproliferative glomerulonephritis; MC, minimal change; MN, membranous nephropathy; FSGS, focal segmental glomerulosclerosis. 
spontaneous remission of NS $(21,22)$. The severe clinical course in our patient, including both viral infections and trauma, may have led to the spontaneous remission.

Investigations into predisposition for thrombosis should be performed in patients with severe or multiple thrombosis. Our patient had no past medical history and/or family history of thromboembolic complications. There were also no findings suggestive of secondary NS, protein C and protein S deficiency, and antiphospholipid syndrome. Whole-exome sequencing revealed a risk variant in the PROS1 gene. This missense variant is rare in the general population, but is often reported in patients with thrombosis or protein S deficiency $(23,24)$. Protein $S$ acts as a cofactor to activated protein $\mathrm{C}$ (APC) in the degradation of factor Va and factor VIIIa $(25,26)$. Approximately $60 \%$ of the protein $\mathrm{S}$ in human plasma is conjugated with $\mathrm{C} 4 \mathrm{~b}$ binding protein, resulting in the complete loss of APC cofactor activity (26). PROS1 variants can affect the secretion of protein $S$, APC cofactor activity, and inhabitation by $\mathrm{C} 4 \mathrm{~b}$-binding protein. A prior study revealed protein $S$ activity and antigen were not markedly decreased in this mutation (24). Although its pathogenicity is not clear, this missense variant could have been one of the risk factors for thrombosis in our patient.

Arterial thrombosis is a rare complication of NS that must be considered in patients with new-onset NS. Early recognition is important in order to initiate treatment promptly and prevent serious sequelae.

\section{REFERENCES}

1. Llach F. Hypercoagulability and thrombotic complications of nephrotic syndrome. Kidney Int. (1985) 28:429-39. doi: 10.1038/ki.1985.149

2. Fahal IH, McClelland P, Hay CR, Bell GM. Arterial thrombosis in the nephrotic syndrome. Postgrad Med J. (1994) 70:9059. doi: 10.1136/pgmj.70.830.905

3. Kauffmann RH, Veltkamp JJ, Van Tilburg NH, Van Es LA. Aquired antithrombin III deficiency and thrombosis in the nephrotic syndrome. Am J Med. (1978) 65:607-13. doi: 10.1016/0002-9343(78)90848-3

4. Suri D, Ahluwalia J, Saxena AK, Sodhi KS, Singh P, Mittal BR, et al. Thromboembolic complications in childhood nephrotic syndrome: a clinical profile. Clin Exp Nephrol. (2014) 18:803-13. doi: 10.1007/s10157-0130917-2

5. Mehls O, Andrassy K, Koderisch J, Herzog U, Ritz E. Hemostasis and thromboembolism in children with nephrotic syndrome: differences from adults. J Pediatr. (1987) 110:862-7. doi: 10.1016/S0022-3476(87)8 0397-9

6. Singhal R, Brimble KS. Thromboembolic complications in the nephrotic syndrome: pathophysiology and clinical management. Thromb Res. (2006) 118:397-407. doi: 10.1016/j.thromres.2005.03.030

7. Kerlin BA, Blatt NB, Fuh B, Zhao S, Lehman A, Blanchong C, et al. Epidemiology and risk factors for thromboembolic complications of childhood nephrotic syndrome: a Midwest Pediatric Nephrology Consortium (MWPNC) study. J Pediatr. (2009) 155:105-10. doi: 10.1016/j.jpeds.2009. 01.070

8. Parrish RA, Scurry RB, Robertson AF 3rd. Recurrent arterial thrombosis in nephrosis. Am J Dis Child. (1976) 130:4289. doi: 10.1001/archpedi.1976.02120050086017

9. Tarry WC, Moser AJ, Makhoul RG. Peripheral arterial thrombosis in the nephrotic syndrome. Surgery. (1993) 114:618-23.

10. Farkas JC, Tabet G, Marzelle J, Cormier F, Laurian C, Cormier JM. Arterial thrombosis: a rare complication of the nephrotic syndrome. Cardiovasc Surg. (1993) 1:265-9.

\section{DATA AVAILABILITY STATEMENT}

The raw data supporting the conclusions of this article will be made available by the authors, without undue reservation, to any qualified researcher.

\section{ETHICS STATEMENT}

Written informed consent was obtained from the minor(s)' legal guardian/next of kin for the publication of any potentially identifiable images or data included in this article.

\section{AUTHOR CONTRIBUTIONS}

HT, YS, TN, and SI assumed clinical duties for this patient. HT and SI reviewed and revised the manuscript. KS and NM provided the whole-exome sequencing findings and revised the manuscript. All authors approved the final case report as submitted and agree to be accountable for all aspects of the work.

\section{ACKNOWLEDGMENTS}

We thank Kelly Zammit, BVSc, from Edanz Editing (www. edanzediting.com/ac), for editing a draft of this manuscript.

11. Cameron JS, Ogg CS, Ellis FG, Salmon MA. Femoral arterial thrombosis in nephrotic syndrome. Arch Dis Child. (1971) 46:215-6. doi: 10.1136/adc.46.2 46.215

12. Harrison BM, Wood CB. Spontaneous femoral artery thrombosis and intermittent claudication in childhood nephrotic syndrome. Arch Dis Child. (1972) 47:836-7. doi: 10.1136/adc.47.255. 836-a

13. Maffei FH, Macedo CS, Lastória S, Castiglia V, Miranda AA. Arterial thrombosis following femoral venipuncture in untreated nephrotic children. $J$ Cardiovasc Surg. (1979) 20:389-91.

14. Büyükçelik M, Karakök M, Başpinar O, Balat A. Arterial thrombosis associated with factor $\mathrm{V}$ Leiden and methylenetetrahydrofolate reductase C677T mutation in childhood membranous glomerulonephritis. Pediatr Nephrol. (2008) 23:491-4. doi: 10.1007/s00467-0070657-1

15. Koh KH, Tan C, Tan S, Ngu L. Arterial thrombosis and critical limb ischaemia in a case of nephrotic syndrome. Nephrology. (2009) 14:622. doi: 10.1111/j.1440-1797.2008.01001.x

16. Han KH, Park JY, Min SK, Ha IS, Cheong HI, Kang HG. Bilateral iliac and popliteal arterial thrombosis in a child with focal segmental glomerulusclerosis. Korean $J$ Pediatr. (2016) 59:242-5. doi: 10.3345/kjp.2016.59.5.242

17. Chinnadurai AV, Marsenic O. Evolving presentation of leg cramps in a child with nephrotic syndrome: answers. Pediatr Nephrol. (2017) 32:2247-52. doi: 10.1007/s00467-0173606-7

18. Lin CY, Hsu HC. Histopathological and immunological studies in spontaneous remission of nephrotic syndrome after intercurrent measles infection. Nephron. (1986) 42:110-5. doi: 10.1159/0001 83647

19. Saeed MB. Varicella-induced remission of steroid-resistant nephrotic syndrome in a child. Saudi J Kidney Dis Transpl. (2004) 15:486-8.

20. Haruki A, Ishikawa E, Katayama K, Ito $T$, Hiramoto $T$, Fujimoto $\mathrm{M}$, et al. Spontaneous remission of adult-onset minimal change 
nephrotic syndrome associated with influenza B infection: a case report. BMC Nephrol. (2018) 19:162. doi: 10.1186/s12882-0180961-y

21. Flohé SB, Flohé S, Schade FU. Invited review: deterioration of the immune system after trauma: signals and cellular mechanisms. Innate Immun. (2008) 14:333-44. doi: 10.1177/1753425908100016

22. Guisasola MC, Alonso B, Bravo B, Vaquero J, Chana F. An overview of cytokines and heat shock response in polytraumatized patients. Cell Stress Chaperones. (2018) 23:483-9. doi: 10.1007/s12192-017-0859-9

23. Tsuda $H$, Urata $M$, Tsuda $T$, Wakiyama $M$, Iida $H$, Nakahara $M$, et al. Four missense mutations identified in the protein $\mathrm{S}$ gene of thrombosis patients with protein $S$ deficiency: effects on secretion and anticoagulant activity of protein S. Thromb Res. (2002) 105:2339. doi: 10.1016/S0049-3848(02)00015-4

24. Ikejiri M, Tsuji A, Wada H, Sakamoto Y, Nishioka J, Ota S, et al. Analysis three abnormal Protein $S$ genes in a patient with pulmonary embolism. Thromb Res. (2010) 125:529-32. doi: 10.1016/j.thromres.2009. 12.025
25. Dahlbäck B. The protein C anticoagulant system: inherited defects as basis for venous thrombosis. Thromb Res. (1995) 77:1-43. doi: 10.1016/0049-3848(94)00138-4

26. Dahlbäck B. Protein S and C4b-binding protein: components involved in the regulation of the protein C anticoagulant system. Thromb Res. (1991) 66:49-61. doi: 10.1055/s-0038-1646373

Conflict of Interest: The authors declare that the research was conducted in the absence of any commercial or financial relationships that could be construed as a potential conflict of interest.

Copyright (C) 2020 Togashi, Shimosato, Saida, Miyake, Nakamura and Ito. This is an open-access article distributed under the terms of the Creative Commons Attribution License (CC BY). The use, distribution or reproduction in other forums is permitted, provided the original author(s) and the copyright owner(s) are credited and that the original publication in this journal is cited, in accordance with accepted academic practice. No use, distribution or reproduction is permitted which does not comply with these terms. 